\title{
Chemical control of branched broomrape in processing tomato using sulfonylureas in Southern Italy
}

\author{
Giulia Conversa, Anna Bonasia, Antonio Elia \\ Department of Agricultural, Food, and Environmental Sciences, University of Foggia, Italy
}

\begin{abstract}
The present research investigated the efficacy and the selectivity of three sulfonylureas (SUs) rimsulfuron (RS), chlorsulfuron (CS) and triasulfuron (TS) for Phelipanche ramosa control in processing tomato. In 2014 a single dose (D) $\left(75,15\right.$ and $22.5 \mathrm{~g} \mathrm{ha}^{-1}$ active ingredient - a.i.- of RS, CS and TS, respectively), split into three applications at equal rate, was delivered into the soil layer interested by the roots using two herbigation methods i) through the drip irrigation system (DH) or ii) by foliar spray followed by overhead irrigation (FH). In 2015 SUs were applied in pre-transplant at one third of $\mathrm{D}$, and in post-transplant at the dose $\mathrm{D}$, at onehalf and at one-fourth of $\mathrm{D}$, delivered in 3 rates by drip herbigation. In both experiments RS gave the best broomrape control and the highest yield increase compared with the untreated crop and CS improved crop yield similarly to RS despite being less effective in contrasting branched broomrape, In 2014, the foliar application of TS and CS resulted in plant injuries which, more significantly with TS, caused lower numbers and fresh weight of fruits as well as a lower crop productivity increase. In the same year the drip herbigation with TS resulted in the lowest broomrape control and tomato yield increase. In 2015, the best parasite control and tomato yield performances were obtained with RS and CS when applied in pre-transplant at 25.0 and $5.0 \mathrm{~g} \mathrm{ha}^{-1}$ a.i., respectively, and in post-transplant at 75.0 and $15.0 \mathrm{~g} \mathrm{ha}^{-1}$ a.i., respectively. With TS, the pre-transplant application a.i. was the most effective among the TS treatments resulting in a yield improvement similar to RS and CS, while it was confirmed the low broomrape control when applied through drip irrigation due to its low mobility in the
\end{abstract}

Correspondence: Giulia Conversa, Department of Agricultural, Food, and Environmental Sciences, University of Foggia, via Napoli 25, 71121 Foggia, Italy.

E-mail: giulia.conversa@unifg.it

Key words: Phelipanche ramosa; Herbigation; Rimsulfuron; Chlorsulfuron; Triasulfuron.

Received for publication: 8 February 2017.

Revision received: 31 March 2017.

Accepted for publication: 1 April 2017.

(C) Copyright G. Conversa et al., 2017

Licensee PAGEPress, Italy

Italian Journal of Agronomy 2017; 12:939

doi:10.4081/ija.2017.939

This article is distributed under the terms of the Creative Commons Attribution Noncommercial License (by-nc 4.0) which permits any noncommercial use, distribution, and reproduction in any medium, provided the original author(s) and source are credited. soil. More research is needed in order to better exploit the combination of pre- and post-transplant applications in the chemical control of P. ramosa of tomato under the conditions in southern Italy.

\section{Introduction}

The Puglia region is among the most important Italian areas for processing tomato with almost 20,000 hectares (ISTAT, 2017) grown annually, $90 \%$ of which are concentrated on the Capitanata Plain, in Foggia province. In this area the crop has been grown successfully for over fifty years thanks to the favourable soil and climatic conditions (Elia and Conversa, 2012).Particularly in this area the crop has been suffering the attack of an obligate root holoparasitic plant belonging to the Orobanchaceae family, Phelipanche ramosa (L.) Pomel (already classified as Orobanche ramosa L.), which has affected tomato cultivation in Southern Italy in the last 20 years (Vurro, 2005).

It is estimated that the $P$. ramosa, commonly known as branched broomrape (locally as sporchia) affects over 5,000 hectares of processing tomato crops, but the figure has been in constant worrying growth over the last five years. There are also a number of reports in the Capitanata area of deleterious attacks of broomrape on other crops such as broccoli, fennel, parsley, celery and chamomile. Substantially the damage caused by broomrape refers to the decrease in productivity of the crop and to the loss of quality of the product. In the case of tomato, the presence of the parasite significantly reduces fruit fresh and dry weight, mesocarp thickness, fruit color, firmness, the soluble solids, ash and ascorbic acid content (Longo et al., 2010).

The chemical control through herbicides of this parasitic plant is based on the principle that the effective application of an active substance must be addressed to the aggression of broomrape before its aboveground appearance, therefore the herbicide must be available at the root zone starting from the initial stages of its biological cycle (seed germination, root attack, formation of tubercles) (Eizenberg et al., 2006). During the crop cycle, the growth of the host plant roots causes a continuous germination of conditioned broomrape seeds, so the availability of the herbicide must be ensured during all the sensitivity phases of the crop (Eizengerg et al., 2012).

Among the proposed herbicides for the control of broomrape, acetolactate synthase (ALS) inhibitors sulfonylureas and imidazolinones have been found to be lethal at relatively low doses both on vegetable and herbaceous crops, but crops may exhibit different tolerance thresholds (Eizenberg et al., 2004, 2012). Imidazolinones are systemic herbicides that are translocated through the roots and the leaves to the meristematic regions. Various Fabaceae, Asteraceae, Apiaceae species are resistant to some of the imidazolinone herbicides, however in tomato plants 
foliar application of imidazolinones (imazapic and imazamox) has been reported to injure flowers and fruit buds (Eizenberg et al., 2013).

Encouraging results have been obtained with sulfonylureas on tomato in several application trials although on a different species of broomrape (P. aegyptiaca, O. cernua) (Hershenhorn et al., 1998a, 1998b, 1998c; Eizenberg et al., 2003; Hershenhorn et al., 2009; Eizenberg et al., 2012; Ghannam et al., 2012; Dinesh and Dhanapal, 2013). The sulfonylureas application for $P$. ramosa control has been successfully performed on glasshouse-grown tomato (Qasem, 1998) and on potato (Goldwasser et al., 2001). The sulfonylurea herbicides are active against broomrapes mainly through the soil solution so they must be incorporated into the soil. Herbicides can be delivered to the target area using mechanical incorporation or by rainfall before host sowing or planting. They can also be delivered into the soil through the irrigation water (herbigation) using either sprinklers or drippers. The success of this mode of herbicide application depends on the availability of herbicide in the soil layer where the host roots are parasitized (Eizenberg, 2013). Taking into account these considerations, in the present research the chemical control of P. ramosa has been performed using three sulfonylureas (SUs) registered in Italy and previously found effective in the control P. aegyptiaca in tomato: rimsulfuron (RS), which is registered for tomato crop, chlorsulfuron (CS) and triasulfuron (TS). The study has been carried out with the aim of evaluating the dose, the application mode of the three sulfonylureas on the efficacy in the control of P. ramosa and in crop selectivity in an environment of southern Italy.

\section{Materials and methods}

Two field trials were carried out in 2014 and 2015 at the Center for Experimentation and Exploitation of Mediterranean Crops of Syngenta located in Foggia ( $41^{\circ} 32^{\prime}$ 38' lat. N $15^{\circ} 30^{\prime}$ '14" long. E), Capitanata Plain, Puglia Region, in Southern Italy. The area is a large plain (about 400,000 ha) mainly cultivated with durum wheat, which is grown in a 3-4 year rotation with tomato, broccoli or sugar beet. The experimental farm is representative of soil and climate conditions on this plain. It is dominated by a Mediterranean climate with a mild winter and dry-and-warm summer. Mean minimum and maximum temperatures are $10.8 \pm 1.7$ and $19.9 \pm 2.2^{\circ} \mathrm{C}$, respectively, and the mean temperature of the coldest (January) and hottest (August) months are 7.1 and 24.5, respectively. Mean annual rainfall is $537 \mathrm{~mm}$ (Elia and Conversa, 2012).

The weather conditions during the two growing seasons are reported in Figure 1. The mean maximum and mean minimum temperatures during the two growing seasons were $28.1^{\circ} \mathrm{C}$ and $14.8^{\circ} \mathrm{C}$ in 2014 (29 Apr.-7 Aug.) and $31.5^{\circ} \mathrm{C}$ and $19.3^{\circ} \mathrm{C}$ in 2015 (8 May-5 Aug.), respectively. In the same period the differences in temperature compared with the long-term averages were -1.3 and $+2.1^{\circ} \mathrm{C}$ in maximum values and +0.1 and $+4.6^{\circ} \mathrm{C}$ in minimum values, in 2014 and 2015, respectively. Rainfall was $116 \mathrm{~mm}$ in 2014 and $73 \mathrm{~mm}$ in 2015 (Figure 1).

The thermal sum was calculated using a base temperature of $10^{\circ} \mathrm{C}$ and considering the average daily temperature of the air or that measured in the middle of the twin row and at $15 \mathrm{~cm}$ of soil depth (Figure 2).

In each year a different field was selected on the same farm. The soil of both fields is a silty-clay vertisol of alluvial origin (1.20 m depth) (Typic Chromoxerert, fine, thermic, according to the Soil Taxonomy-USDA), with the following characteristics: $24 \%$ clay;
$34 \%$ silt; $42 \%$ sand; $\mathrm{pH} 7.72$ (soil:water 1:2.5); $1.8 \%$ organic matter; $1.25 \%$ total $\mathrm{N}, 382 \mathrm{mg} \mathrm{kg}^{-1} \mathrm{NH}_{4} \mathrm{OAc}$-extractable $\mathrm{K}, 9.7 \%$ active $\mathrm{CaCO}_{3} .25 \mathrm{mg} \mathrm{kg}^{-1}$ Olsen P. In both trials the preceding crop was a cover crop (Raphanus sativus L. cv. Valencia) sown in the preceding winter (12 Dec. 2013 and 16 Dec. 2014) and tilled into the soil about one month before tomato transplanting. At the time of soil preparation before transplanting, 120 and $200 \mathrm{~kg} \mathrm{ha}^{-1}$ of $\mathrm{P}_{2} \mathrm{O}_{5}$ and $\mathrm{K}_{2} \mathrm{O}$, respectively, were broadcasted. The transplanting of processing tomato [Solanum lycopersicum L. (formerly Lycopersicon esculentum Mill.)] at the $4^{\text {th }}$ true-leaf stage, was performed on 29 Apr. 2014 (experiment 1) and on 8 May 2015 (experiment 2) with the cultivar Robinux (Syngenta) in 2014 and Ulisse (Syngenta) in 2015, both of them belonging to the pear shaped fruit typology. Plantlets were spaced in twin-rows at $37 \mathrm{~cm}$ apart and between the rows, and $1.8 \mathrm{~m}$ between the double-rows (density of 3.0 plants $\mathrm{m}^{-2}$ ).

In both years crop water requirements were completely satisfied by drip irrigation (drip tube - Agrifim, in line emitters, $2 \mathrm{~L} \mathrm{~h}^{-1}$, spaced $0.4 \mathrm{~m}, 1$ dripping line for each twin row). The nitrogen fertilizer was applied by fertigation during the crop cycle. Irrigation water volume and $\mathrm{N}$ rate management was assessed using the DSS GesCoN (Elia and Conversa, 2015), set with the parameters proposed for processing tomato (Conversa et al., 2015). A total of 198 and $186 \mathrm{~kg} \mathrm{ha}^{-1}$ of $\mathrm{N}$ and an irrigation volume of 4,560 and 4,700 $\mathrm{m}^{3} \mathrm{ha}^{-1}$ were applied in 2014 and 2015, respectively.

Excluding broomrape, the other weeds were controlled by hand; pests and diseases were completely controlled by chemical treatments.

In the first year the comparison was carried out between: i) three herbicides: rimsulfuron (RS), chlorsulfuron (CS) and triasulfuron (TS), and the untreated control (C); ii) two herbigation techniques: i) distribution through the irrigation water using the drip system (DH) and ii) distribution through foliar spray (FH), followed by an overhead sprinkler irrigation of $30 \mathrm{~mm}$ of water to ensure the incorporation of the herbicide into the soil at the root level. The water irrigation volume used with overhead irrigation was considered in the water balance.

The dose (D) of RS, CS and TS was respectively 75.0, 15.0 and $22.5 \mathrm{~g} \mathrm{ha}^{-1}$ of active ingredient (a.i.) distributed into three split applications at equal rates $\left(25.0,5.0\right.$ and $7.5 \mathrm{~g} \mathrm{ha}^{-1}$ a.i., respectively). The applications were carried out during the growing season at 30 (28 May), 50 (17 Jun.) and 70 (7 Jul.) days after the transplant (DAT). There were obtained the following six treatments: $\mathrm{RS}_{\mathrm{DH}}$, $\mathrm{RS}_{\mathrm{FH}}, \mathrm{TS}_{\mathrm{DH}}, \mathrm{TS}_{\mathrm{FH}}, \mathrm{CS}_{\mathrm{DH}}$ and $\mathrm{CS}_{\mathrm{FH}}$.

For drip herbigation, the herbicide for each plot was diluted in $20 \mathrm{~L}$ of water and injected by a Venturi tube into the drip system used for the irrigation. Herbicide treatments were applied after irrigating $90 \mathrm{~m}^{3} \mathrm{ha}^{-1}$ of water and were followed by $30 \mathrm{~min}$ of additional irrigation.

When herbicides were foliar sprayed they were applied through a knapsack sprayer (SHR-170SI Echo, Altavilla Vicentina, VI, Italy) equipped with a $1.5 \mathrm{~m}$ spraying boom with 3 TeeJet XR8003 nozzles, at a pressure of $300 \mathrm{kPa}$, delivering $300 \mathrm{~L} \mathrm{ha}^{-1}$.

In the second trial (2015), RS, CS and TS were applied in pretransplant (Pre) and in post-transplant drip herbigation (Post). In the pre-transplant treatment, the application dose used for each herbicide was $1 / 3$ of that used in first experiment (one rate, D/3) (25.0, 5.0 and $7.5 \mathrm{~g} \mathrm{ha}^{-1}$ a.i., for RS, CS and TS, respectively. These treatments are coded with $\mathrm{RS}_{\operatorname{Pre}(\mathrm{D} / 3),}, \mathrm{CS}_{\mathrm{Pre}(\mathrm{D} / 3)}$ and $\mathrm{TS}_{\operatorname{Pre}(\mathrm{D} / 3) \text {. }}$

The application was carried out by spraying the herbicide on the soil surface using a Teko 800 sprayer (Unigreen S.p.a., Reggio Emilia, Italy) equipped with a 2 or a $4 \mathrm{~m}$ spraying boom with 03 F110 nozzles, at a pressure of $300 \mathrm{kPa}$, delivering $312 \mathrm{~L} \mathrm{ha}^{-1}$, with 
subsequent mechanical incorporation into the soil $(\sim 10-15 \mathrm{~cm})$. The post-transplant treatments were carried out by drip herbigation (as described in the first year). The doses of Post treatments were obtained by applying RS, TS and CS at the same dose (D), at $1 / 2$ the dose $(\mathrm{D} / 2)$ and $1 / 4$ the dose $(\mathrm{D} / 4)$ used in the first experiment, split in 3 applications at equal rate during the crop cycle at 30 (6 Jun.) and 50 (26 Jun.) and 70 (16 Jul.) DAT, respectively. The obtained treatments are indicated as: $\mathrm{RS}_{\text {Post(D), }}, \mathrm{RS}_{\text {Post(D/2) }}, \mathrm{RS}_{\text {Post(D/3) }}$, $\mathrm{TS}_{\text {Post(D) }}, \mathrm{TS}_{\text {Post(D/2) }}, \mathrm{TS}_{\text {Post(D/3) }}, \mathrm{CS}_{\text {Post(D) }}, \mathrm{CS}_{\text {Post(D/2) }}, \mathrm{CS}_{\text {Post(D/3). }}$

Broomrape infestation was measured by counting the emerging parasite stems during the tomato growing cycles. Two broomrape surveys were performed in both 2014 [9 Jul. (71 DAT) and at harvest, 7 Aug. (101 DAT)] and 2015 [16 Jul. (69 DAT) and at harvest, 5 Aug. (90 DAT)]. At harvest the fruit yield from 12 tomato plants ( $\sim 4 \mathrm{~m}^{2}$ of sampling area per replication) was also recorded.

In both years the experimental plots, which included four (two twin rows) $11.6 \mathrm{~m}$ long tomato rows (132 plants), were distributed in a randomized block design with four replications. All the data were submitted to ANOVA by using the GLM Procedure of SAS software (SAS Institute, 1999). When the main effects were significant, differences between means were compared using the LSD test at $\mathrm{P}=0.05$. Planned, single degree-of-freedom orthogonal contrasts were used for partitioning the treatment sum of squares to gain greater insight among the group of treatments. The linear relationships between the infestation level of branched broomrape and the tomato fruit yield, was also evaluated.

\section{Results and discussion}

\section{Effect of the year on broomrape occurrence}

In the first trial a higher branched broomrape infestation was registered compared with the second experiment. Indeed in the untreated control broomrape density reached 400 (Figure 3) and 237 spears $/ \mathrm{m}^{2}$ in the first and in the second experiment, respectively (Tables 1 and 2). In addition, in first year the emergence of broomrape spears was observed mainly in the last 30 days of the crop cycle. In the first survey, carried out at 71 DAT, a very low infestation was registered both in the control and in the herbigated plots compared with at the end of the tomato cycle (Table 1). In the second trial, in the broomrape survey performed at 50 DAT, no differences between treatments were detected (data not shown), on the contrary, at 69 DAT the infestation was similar to the highest level observed at the end of the tomato cycle (89 DAT - 5 Aug.) (Table 2).

The difference between trials in the time of broomrape attack and in broomrape spear density is likely to be linked to the different environmental conditions before transplant and during the crop cycle. Seeds of parasitic plants only germinate in response to germination stimulants present in the exudates from host roots (Joel et al., 1995; Dhanapal et al., 1996). However, seeds become progressively sensitive to germination stimulants only after the release from dormancy following a period of wet conditions (conditioning) immediately before germination (Murdoch and Kebreab, 2013). The efficiency of the conditioning phase depends on the duration of the wet conditions and on the soil temperature. In $P$. ramosa the range of soil temperature for dormancy release has been reported to be $5-30{ }^{\circ} \mathrm{C}$, with an optimum at $20^{\circ} \mathrm{C}$ for a period of 14-100 days and subsequent maximal germination rate. However a prolonged conditioning at suboptimal temperatures (5 or $30^{\circ} \mathrm{C}$ ) resulted in an induction of secondary dormancy of seeds, which showed a very low germination rate (Gibot-Leclerc et al., 2004).

In our study, in both years the mean soil temperature was close to $15^{\circ} \mathrm{C}$ for a period of $30-40$ days before the transplant (data not shown), which is very close to the optimal value $\left(20^{\circ} \mathrm{C}\right)$ for $P$. ramosa seed conditioning. However, the higher rainfall that occurred during this phase in 2014 (Figure 1) could have improved soil moisture resulting in the conditioning of a larger number of broomrape seeds compared with 2015. In 2015 the higher soil and air thermal sum in the first part of the cycle (Figure 2) could have promoted a faster root growth and so an earlier broomrape infestation. The infestation slowly increased in the last part of the cycle because of the high temperature values could have resulted in secondary dormancy induction of broomrape seeds. Moreover the large amplitude of minimum and maximum daily values in the last part of the cycle could have also reduced germination rate as supposed by Kebreab and Murdoch (1999) in Egyptian broomrape (Figure 1).

\section{Experiment 1 - Effect of herbicide application mode on broomrape density and crop productivity}

At 71 DAT, while in the untreated control broomrape spear density was already relevant $\left(68\right.$ spears $\left./ \mathrm{m}^{2}\right)$, in the herbigated plots the parasite emergence was still rather low. At the broomrape survey performed at harvest (100 DAT), the difference in $P$. ramosa infestation between the untreated and the treated plots had increased compared with the first broomrape survey, and all the

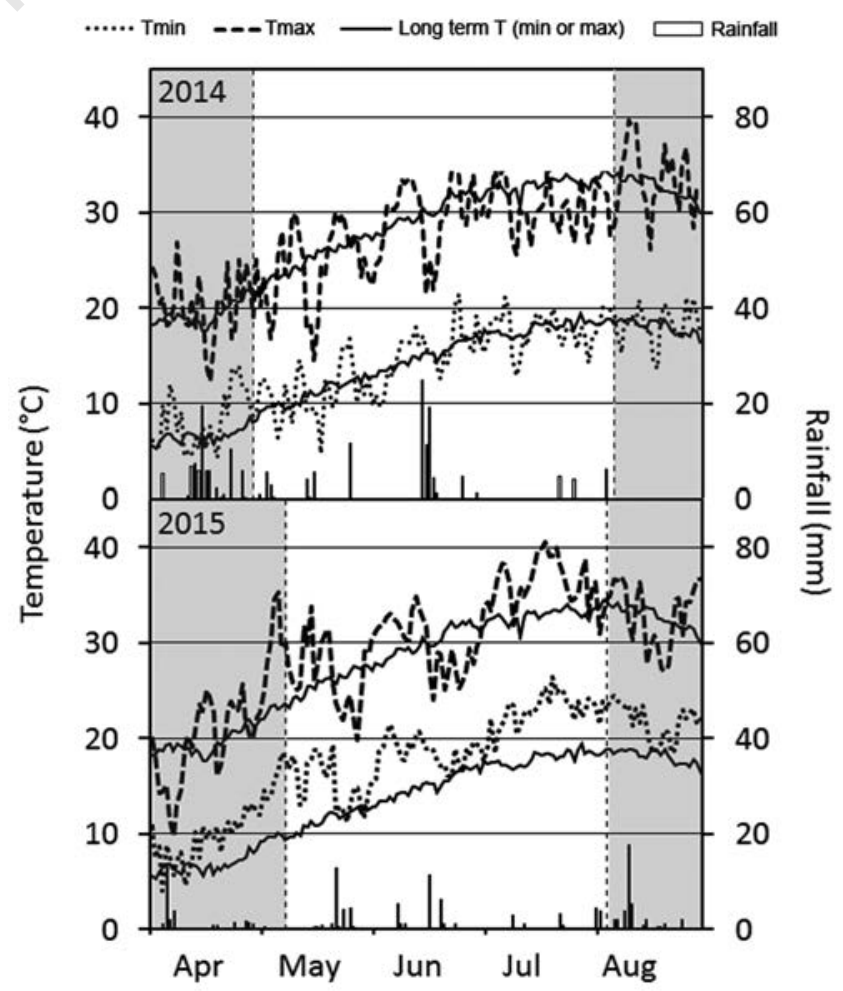

Figure 1. Minimum, maximum temperatures, compared with multiannual averaged values, and rainfall in the 2014 and 2015 growing seasons. 
treated plots showed a significant reduction in broomrape spear emergence compared with the untreated control (400 spears $/ \mathrm{m}^{2}$ ) (Table 1, contrasts no. 1, 2, 3 and 4, highly significant).

The productivity of the crop was clearly affected by the $P$. ramosa infestation since the yield of the untreated control was about $24 \mathrm{Mg} \mathrm{ha}^{-1}$ while in rimsulfuron (RS), triasulfuron (TS) and clorsulfuron (CS) treated plots it was, respectively, 101.3, 48.6 and $77.4 \mathrm{Mg} \mathrm{ha}^{-1}$, on average (Table 1 , contrasts no. 1,2, 3, and 4, highly significant).

At 100 DAT rimsulfuron at the dose used in this study $(25.0 \mathrm{x}$ $3=75.0 \mathrm{~g} \mathrm{ha}^{-1}$ a.i.), irrespective of the application mode, gave the lowest broomrape infestation (-90\%, on average) and the highest yield increase $(+417 \%)$ compared with the untreated control (Table 1$)$.

Beyond the effectiveness in controlling branched broomrape, RS also showed high crop selectivity. Although the labelled RS dose for post-emergence weed control in tomato ranges between 12.5-22.5 $\mathrm{g} \mathrm{ha}^{-1}$ a.i., we did not detect crop injuries with the higher dose used in the trial and the tomato yield was within the optimal average level for the area. This result is in agreement with previous researches on rimsulfuron application for the control of $P$. aegyptiaca. RS doses of 150 (Eizenberg et al., 2004), 75.0 (Kleifeld et al., 1994) and of 50.0 - $37.5 \mathrm{~g} \mathrm{ha}^{-1}$ a.i. (Eizenberg et al., 2003) split into 3 applications by foliar herbigation have proved to be effective in the control of $P$. aegyptiaca, without crop injuries in tomato. Similarly Goldwasser et al. (2001) have reported selectivity for potato crop of RS at 37.5 and $75.0 \mathrm{~g} \mathrm{ha}^{-1}$ a.i. When the herbigation was performed by drip system (DH) fruit number per plant was lower than $\mathrm{RS}_{\mathrm{FH}}$. However an enhancement of $\mathrm{RS}_{\mathrm{DH}}$ mean fruit weight resulted in yield performance similar between the two distribution systems.

It has been reported that RS interferes with the tubercle development and not with broomrape attachment (Kleifeld et al., 1994). Drip herbigation performed in a single application at 23 DAT has been reported to have a lower effect in controlling broomrape compared with foliar spraying+sprinkler irrigation, due to the poorer distribution uniformity (Hershenhorn et al., 1998a). In our trial, both herbigation systems allowed RS to reach root apparatus along the tomato cycle, both proving to be effective in controlling broomrape. Likely the efficiency of the drip herbigation in our trials was due to the splitted application in three rates during the crop cycle.

Contrarily to rimsulfuron, triasulfuron is not registered for tomato crops. It is suggested for post-emergence weed control of wheat (and other cereals) and tomato can be planted the following season of TS application without restrictions. In our trial it was applied at the labeled doses.

TS efficiency in controlling broomrape was lower than RS (Table 1, contrast no. 5, significant at $\mathrm{P} \leq 0.05$ ) however it depended on the distribution system. Indeed, when TS was sprayed over the crop and incorporated into the soil using sprinkler irrigation $\left(\mathrm{TS}_{\mathrm{FH}}\right)$ the parasite control was very similar to RS $(93 \%$ reduction in

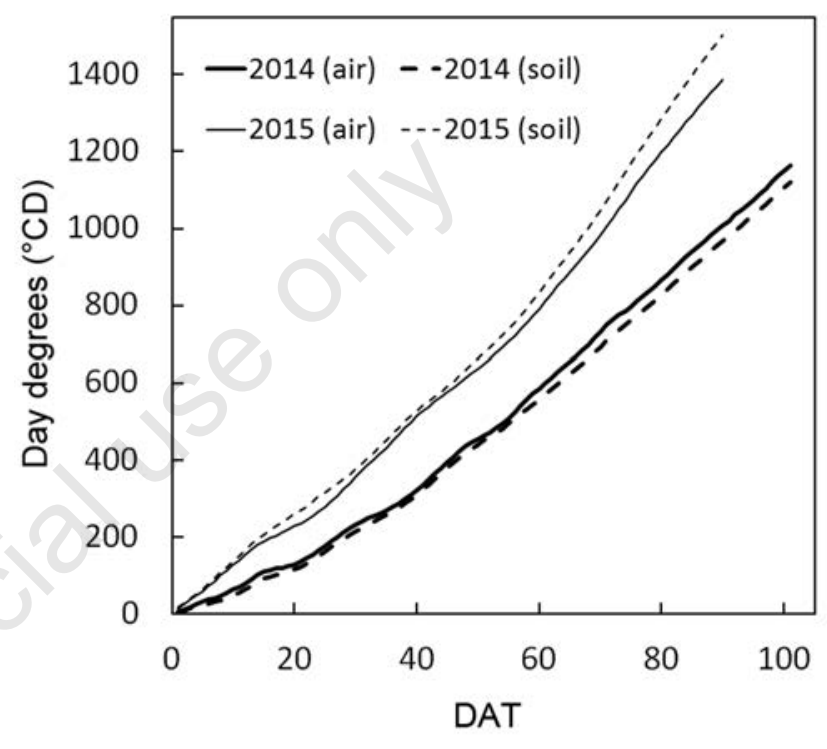

Figure 2. Cumulative day-degrees in the air (solid line) and at 15cm soil depth (dashed line) in the 2014 (broad line) and 2015 (smooth line) trials.

Table 1. Effect of herbigation treatments on Phelipanche ramosa emergence and tomato yield in the 2014 trial.

\begin{tabular}{|c|c|c|c|c|c|c|c|}
\hline Herbicide & $\begin{array}{l}\text { Treatment } \\
\text { Appl. mode }\end{array}$ & Code & $\begin{array}{r}\text { Phelipanche r } \\
71 \text { DAT }\end{array}$ & $\begin{array}{l}\text { stems (no. } \mathrm{m}^{-2} \text { ) } \\
100 \text { DAT }\end{array}$ & $\begin{array}{l}\text { Tomato yield } \\
\left(\mathrm{Mg} \mathrm{ha}^{-1}\right)\end{array}$ & $\begin{array}{l}\text { Fruits per plant } \\
\text { (no.) }\end{array}$ & $\begin{array}{l}\text { Mean fruit weight } \\
\text { (g) }\end{array}$ \\
\hline RS & $\mathrm{DH}$ & $\mathrm{RS}_{\mathrm{DH}}$ & $4^{b}$ & $41^{\mathrm{c}}$ & $95.9^{\mathrm{ab}}$ & $43.7^{\mathrm{b}}$ & $73.9^{\mathrm{a}}$ \\
\hline RS & $\mathrm{FH}$ & $\mathrm{RS}_{\mathrm{FH}}$ & $0 \mathrm{~b}$ & $41^{\mathrm{c}}$ & $106.7^{\mathrm{a}}$ & $60.0^{\mathrm{a}}$ & $59.7^{\mathrm{ac}}$ \\
\hline TS & $\mathrm{DH}$ & $\mathrm{TS}_{\mathrm{DH}}$ & $0^{\mathrm{b}}$ & $241^{\mathrm{ab}}$ & $51.2^{\mathrm{d}}$ & $23.6^{\mathrm{c}}$ & $73.2^{\mathrm{a}}$ \\
\hline TS & $\mathrm{FH}$ & $\mathrm{TS}_{\mathrm{FH}}$ & $14^{b}$ & $28^{c}$ & $46.1^{\mathrm{d}}$ & $30.6^{\mathrm{c}}$ & $50.7^{c}$ \\
\hline CS & $\mathrm{DH}$ & $\mathrm{CS}_{\mathrm{DH}}$ & $11^{\mathrm{b}}$ & $128^{\mathrm{bc}}$ & $86.6^{\mathrm{b}}$ & $43.7^{\mathrm{b}}$ & $66.6^{\text {ab }}$ \\
\hline CS & $\mathrm{FH}$ & $\mathrm{CS}_{\mathrm{FH}}$ & $4^{b}$ & $127^{\mathrm{bc}}$ & $68.2^{c}$ & $46.3^{b}$ & $49.3^{c}$ \\
\hline Control & - & Ctrl & $68^{\mathrm{a}}$ & $400^{\mathrm{a}}$ & $24.3^{\mathrm{e}}$ & $13.8^{\mathrm{d}}$ & $57.7^{\mathrm{bc}}$ \\
\hline \multicolumn{3}{|l|}{ Significance } & $* * *$ & $* *$ & $* * *$ & $* * *$ & $*$ \\
\hline \multicolumn{8}{|c|}{ Contrasts } \\
\hline \multicolumn{3}{|c|}{ 1. Hericides us Ctrl } & $* * *$ & $* *$ & $* * *$ & $* * *$ & ns \\
\hline \multicolumn{3}{|c|}{ 2. RS vs Ctrl } & $* * *$ & $* * *$ & $* * *$ & $* * *$ & ns \\
\hline \multicolumn{3}{|l|}{ 3. TS us Ctrl } & $* * *$ & $* * *$ & $*$ & $* * *$ & ns \\
\hline \multicolumn{3}{|l|}{ 4. CS vs Ctrl } & $* * *$ & $* * *$ & $* * *$ & $* * *$ & ns \\
\hline \multicolumn{3}{|l|}{ 5. RS vs TS } & ns & $*$ & $* * *$ & $* * *$ & ns \\
\hline \multicolumn{3}{|l|}{ 6. RS us CS } & ns & ns & $* * *$ & $*$ & ns \\
\hline \multicolumn{3}{|l|}{ 7. TS us CS } & ns & ns & $* * *$ & $* * *$ & ns \\
\hline \multicolumn{3}{|l|}{ 8. DH vs FH } & ns & $*$ & ns & $* * *$ & $* * *$ \\
\hline
\end{tabular}

DAT, days after the transplant; RS, rimsulfuron, applied at the dose of $75.0 \mathrm{~g} \mathrm{ha}^{-1}$ of a.i. (25.0 $\mathrm{g}$ ha ${ }^{-1}$ of a.i. for each application); a.i., active ingredient; $\mathrm{DH}$, drip herbigation; FH, foliar spray followed by a sprinkler irrigation of $30 \mathrm{~mm}$ of water; TS, triasulfuron, applied at the dose of $22.5 \mathrm{~g} \mathrm{ha}^{-1}$ of a.i. ( $7.5 \mathrm{~g} \mathrm{ha}^{-1}$ of a.i. for each application); CS, chlorsulfuron, applied at the dose of $15.0 \mathrm{~g}$ ha ${ }^{-1}$ of a.i. (5.0 $\mathrm{g}$ ha ${ }^{-1}$ of a.i. for each application) ${ }^{*} \mathrm{P} \leq 0.05 ;{ }^{* *} \mathrm{P} \leq 0.01 ;{ }^{* * *} \mathrm{P} \leq 0.001 ; \mathrm{ns}$, not significant. ${ }^{\mathrm{a}-\mathrm{e}} \mathrm{Means}$ in columns not sharing the same letters are significantly different according to least significant difference test (P=0.05). 
broomrape spears), while when TS was applied by drip irrigation $\left(\mathrm{TS}_{\mathrm{DH}}\right)$ it was the lowest ( $40 \%$ reduction in P. ramosa spears). With this latter distribution method this herbicide seems to fail to ensure a full protection of the root apparatus, most likely as a result of its low soil mobility (Walker and Welch, 1989). As confirm of its low mobility, TS applied by drip herbigation caused a broomrape spears emergence about $30 \mathrm{~cm}$ from either side of the dripping line (Figure 4), creating only a strip free of broomrape along and in the center of the double row.

Despite $\mathrm{TS}_{\mathrm{FH}}$ exhibiting the best $P$. ramosa control, phytotoxic effects were detected on the $\mathrm{TS}_{\mathrm{FH}}$ treated plants (temporary yellowing, delayed growth) and the yield improvement compared to the untreated control was very similar between $\mathrm{TS}_{\mathrm{FH}}$ and $\mathrm{TS}_{\mathrm{DH}}(200 \%$, on average) (Table 1). Based on these results, it could be suppose that the broomrape attack in $\mathrm{TS}_{\mathrm{DH}}$ and the foliar distribution of TS exerted crop damage at the same extend. The beneficial effect of TS on crop productivity was lower than RS and CS and it was due to a lower number of fruits per plant registered both in $\mathrm{TS}_{\mathrm{DH}}$ and $\mathrm{TS}_{\mathrm{FH}}(27$, on average) in comparison with RS (52, on average) and CS (44, on average) (Table 1, contrasts no. 5 and 7 , significant at $\mathrm{P} \leq 0.001)$. Moreover, in $\mathrm{TS}_{\mathrm{FH}}$ it was observed a lower mean weight of the fruits than with $\mathrm{TS}_{\mathrm{DH}}$ treatment, although yield was not significantly affected. It could be speculate that behind the negative effect on plant development, which reduced fruit number (TS could have negatively affected pollination and/or fecundation and/or fruit set as suggested by Hershenhorn et al., 2009), the foliar spray treatment caused physiological alterations (e.g. lower photosynthetic activity) which resulted in reduced plant and fruit growth.

The TS plant injuries observed in this study are in disagreement with other studies performed on tomato crops treated both by drip and foliar application, also using a higher dose $\left(22.5 \mathrm{~g} \mathrm{ha}^{-1}\right.$ a.i. in one sprinkler application at $30 \mathrm{DAT}$, or $7.5,11.25,15 \mathrm{~g} \mathrm{ha}^{-1}$ a.i. by drip herbigation in one application at 23 DAT) (Hershenhorn et al., 1998a) than those in this research $\left(7.5 \mathrm{~g} \mathrm{ha}^{-1}\right.$ a.i. in three splitted rates). This could be associated with the earlier TS applications carried out by these Authors (15 and 30 DAT, i.e. before the developmental phase of the crop) than those of our trial. As triasulfuron, chlorsulfuron is not registered for tomato crop weed control, it has a longer soil activity than most other sulfonylureas. It was not significantly less effective than rimsulfuron and triasulfuron in contrasting branched broomrape (Table 1, contrasts no. 6 and 7, not significant), however, mean yield enhancement compared the untreated control with CS $(+318 \%$, on average) was lower than RS $(+417 \%)$. In particular, the application mode affected crop productivity with a lower yield linked to lower mean fruits weight observed when the herbicide was applied by the foliar spray $\left(\mathrm{CS}_{\mathrm{FH}}\right)$. This result could have been the effect of slight injuries to plant shoots observed after the CS foliar applications which reduced fruit growth. As a consequence the positive effect on crop productivity compared with untreated control was higher in $\mathrm{CS}_{\mathrm{DH}}(+357 \%)$ than in $\mathrm{CS}_{\mathrm{FH}}(+280 \%)$. Our results are in agreement with those obtained by Hershenhorn et al. (1998a) who report that this herbicide is effective in the control of Phelipanche spp. both by drip and foliar application with only transitory and not heavy signs of injury to tomato crop. As a whole, the results of the first experiment underline that each of the active ingredients tested was effective in controlling $P$. ramosa in tomato crop and that the drip herbigation was a valid option for all three herbicides application, since it avoided any crop injury and any negative effect on crop yield observed for TS and CS. Only for TS, did the drip herbigation prove to be less effective in broomrape control due to the limited distribution uniformity of the a.i. into the soil through irrigation water.

\section{Experiment 2 - Effect of herbicides dose and applica- tion time on broomrape control through drip irrigation}

The weakest point of drip herbigation is associated with the higher risk of underground water pollution because of the potential leaching of herbicides, therefore the use of lower herbicide doses is desirable in order to minimise this risk. In the first trial we chose

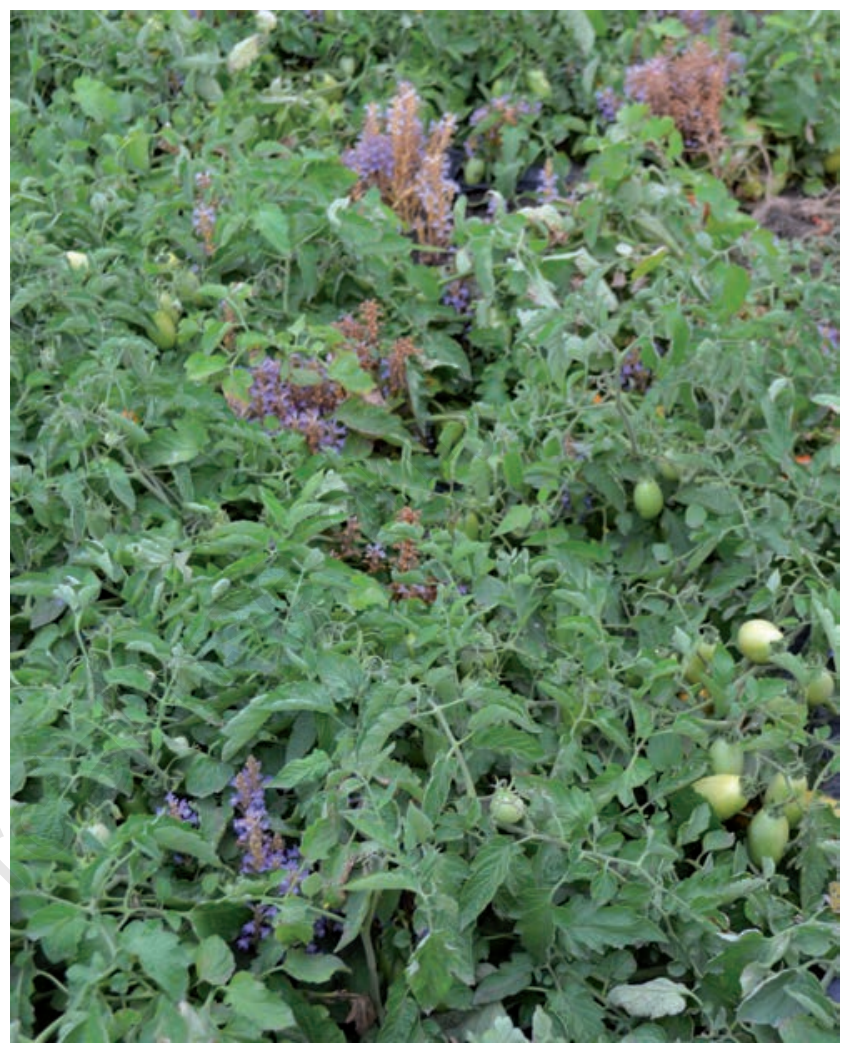

Figure 3. High infestation of branched broomrape observed on tomato plants in the 2014 trial. The number of broomrape stems in the untreated control was close to 400 per square meter.

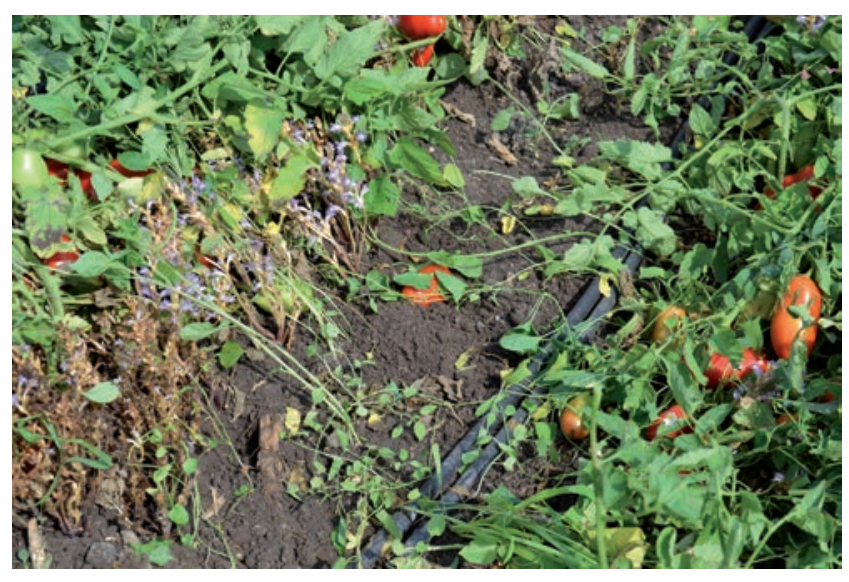

Figure 4. The drip herbigation with triasulfuron caused the emergence of broomrape spears at about $30 \mathrm{~cm}$ from either side of the dripping line. Due to the low mobility of this herbicide in the soil, triasulfuron failed to ensure a full protection of the root apparatus. 
to apply high herbicide doses because we knew about the heavy broomrape infestation of the site. In the second trial the broomrape control was performed with the same 2014 dose along with reduced doses of RS, TS and CS applied only through drip herbigation. With the aim of overcoming the above described issue of low mobility of TS in the soil, a double drip line for each twin row was also arranged only for this herbicide. A pre-transplant application was also tested in the attempt to improve herbicide effectiveness. Broomrape spear emergence was already relevant in the broomrape survey performed at two thirds of the tomato cycle (69 DAT) when only two applications for every post-transplant treatment had been performed and all the herbicides reduced the parasite infestation. The differences between treatments were already observed at 69 DAT, but they were more evident at the end of the tomato cycle (Table 2, contrast no. 1, significant for $\mathrm{P} \leq 0.001$ ) and for this reason we only discuss the infestation data recorded in the last broomrape survey. As an average among post-transplant treatments the best broomrape control was obtained with RS (-65\%, compared untreated plots) and CS (-52\%) followed by and TS ($26 \%$ ) (Table 2, contrasts no. 2, 3 and 4, respectively, significant for $\mathrm{P} \leq 0.001$,), confirming the results of the first trial. The worst performance in $P$. ramosa control was again registered with TS, despite the use in this trial of a double dripping line for this herbicide to improve its distribution uniformity.

Looking at the herbigation dose, for each herbicide the parasite control progressively decreased decreasing the dose (Table 2, contrasts no. 5, 6, and 7, significant at $\mathrm{P} \leq 0.001$ ). Indeed, the highest dose of $\mathrm{RS}\left(\mathrm{RS}_{\text {Post(D) }}\right)$ resulted in a $90 \%$ reduction in parasite spear density compared to the control (237 stems $\left./ \mathrm{m}^{2}\right)$. When the RS dose was halved from $75\left(\mathrm{RS}_{\text {Post(D) }}\right)$ to $37.5\left(\mathrm{RS}_{\mathrm{Post}(\mathrm{D} / 2)}\right)$ and to 18.5
$\left(\mathrm{RS}_{\mathrm{Post}(\mathrm{D} / 4)}\right) \mathrm{g} \mathrm{ha}^{-1}$ a.i. the $P$. ramosa control was reduced by $57 \%$ and $47 \%$, respectively. With post-transplant TS herbigation, the highest infestation overall treatments was detected with the lowest dose $\left(5.625 \mathrm{~g} \mathrm{ha}^{-1}\right.$ a.i.) $\left(\mathrm{TS}_{\text {Post(D/4) }}\right)\left(198 \mathrm{spears} / \mathrm{m}^{2}\right)$ while with the high $\left(\mathrm{TS}_{\mathrm{Post}(\mathrm{D})}\right)$ and medium doses $\left(\mathrm{TS}_{\mathrm{Post}_{\mathrm{D} / 2)}}\right)$ the $P$. ramosa presence was respectively $34 \%$ and $27 \%$ of the untreated plots. With $\mathrm{CS}$ in post-transplant herbigation at the highest dose $\left(\mathrm{CS}_{\text {Post(D) }}\right)$ a decrease of $73 \%$ in broomrape emergence was observed compared with control. Lower infestation reductions were obtained with the lower CS doses (- 49\% and $-35 \%$ with $\mathrm{CS}_{\text {Post(D/2) }}$ and $\mathrm{CS}_{\text {Post(D/4), }}$ respectively) (Table 2).

By considering the pre-transplant herbicide application it emerged an improved $P$. ramosa control compared to post-transplant application (Table 2, contrast no. 8, significant at $\mathrm{P} \leq 0.001$ ) and $\mathrm{RS}_{\mathrm{Pre}(\mathrm{D} / 3)}$ treatment was more effective than $\mathrm{CS}_{\operatorname{Pre}(\mathrm{D} / 3)}$ and particularly than $\mathrm{TS}_{\operatorname{Pre}(\mathrm{D} / 3)}$. The treatment $\mathrm{RS}_{\operatorname{Pre}(\mathrm{D} / 3)}$ resulted in an higher reduction $(-81 \%)$ in parasite spears compared to $\mathrm{RS}_{\text {Post(D/2) }}(-57 \%)$ and $\mathrm{RS}_{\text {Post(D/4) }}(-49 \%)$ treatments in which doses close to $\mathrm{RS}_{\mathrm{Pre}(\mathrm{D} / 3)}$ were given post-transplant split in three rates (Table 2). This result indicates that $\mathrm{RS}$ applied at $25 \mathrm{~g} \mathrm{ha}^{-1}$ a.i. before the transplant is more effective than if doses ranging from 37-19 $\mathrm{g} \mathrm{ha}^{-1}$ a.i. were applied by herbigation during the crop cycle (Table 2). Similar behavior can be reported for CS, since $\mathrm{CS}_{\mathrm{Pre}(\mathrm{D} / 3)}$ exhibited a better broomrape control than $\mathrm{CS}_{\text {Post }(\mathrm{D} / 2)}(-49 \%)$ and $\mathrm{CS}_{\text {Post }(\mathrm{D} / 4)}(-35 \%)$. By the way, pre-transplant application of $\mathrm{CS}$ at $5.0 \mathrm{~g} \mathrm{ha}^{-1}$ a.i. $\left(\mathrm{CS}_{\operatorname{Pre}(\mathrm{D} / 3)}\right)$ was effective as much as post-transplant application of $15.0 \mathrm{~g} \mathrm{ha}^{-1}$ a.i. given split in three rates $\left(\mathrm{CS}_{\text {Post(D) }}\right)$. With regard to $\mathrm{TS}$, it is interesting to highlight that when it was applied in pretransplant it was the most effective among all TS treatments, even showing a broomrape control only by a little lower compared to

\section{Table 2. Effect of herbicide treatments on Phelipanche ramosa emergence and tomato yield in the 2015 trial.}

\begin{tabular}{|c|c|c|c|c|c|c|c|c|c|}
\hline Herbicide & $\begin{array}{l}\text { Appl. } \\
\text { time }\end{array}$ & $\begin{array}{l}\text { Appl. dose } \\
\text { (g hatment a.i.) }\end{array}$ & Code & $\begin{array}{r}\text { Phelipanc } \\
69 \text { DAT }\end{array}$ & amos & $\begin{array}{l}\left.\text { ns (no. } \mathrm{m}^{-2}\right) \\
89 \mathrm{DAT}\end{array}$ & $\begin{array}{c}\text { Tomato } \\
\text { yield } \\
\left(\mathrm{Mg} \mathrm{ha}^{-1}\right)\end{array}$ & $\begin{array}{c}\text { Fruits } \\
\text { per plant } \\
\text { (no.) }\end{array}$ & $\begin{array}{l}\text { Mean fruit } \\
\text { weight } \\
\text { (g) }\end{array}$ \\
\hline $\mathrm{RS}$ & Pre & $\mathrm{D} / 3$ & $\mathrm{RS}_{\operatorname{Pre}(\mathrm{D} / 3)}$ & $33.7^{\mathrm{gh}}$ & & $43.8^{\mathrm{i}}$ & $88.5^{\mathrm{a}}$ & $65.1^{\mathrm{a}}$ & $71.1^{\mathrm{a}}$ \\
\hline $\mathrm{RS}$ & Post & $\mathrm{D}$ & $\mathrm{RS}_{\text {Post(D) }}$ & $15.7^{\mathrm{h}}$ & & $22.7^{\mathrm{j}}$ & $91.3^{\mathrm{a}}$ & $67.2^{\mathrm{a}}$ & $74.4^{\mathrm{a}}$ \\
\hline $\mathrm{RS}$ & Post & $\mathrm{D} / 2$ & $\mathrm{RS}_{\text {Post(D/2) }}$ & $83.3^{\text {de }}$ & & $102.7^{\mathrm{f}}$ & $75.5^{\mathrm{bc}}$ & $62.9^{\mathrm{ac}}$ & $56.7^{\mathrm{cd}}$ \\
\hline $\mathrm{RS}$ & Post & $\mathrm{D} / 4$ & $\mathrm{RS}_{\text {Post(D/4) }}$ & $94.4^{\mathrm{d}}$ & & $121.6^{\mathrm{e}}$ & $74.3^{\mathrm{bc}}$ & $55.2^{\mathrm{ad}}$ & $57.2^{\mathrm{cd}}$ \\
\hline TS & Pre & $\mathrm{D} / 3$ & $\mathrm{TS}_{\mathrm{Pre}(\mathrm{D} / 3)}$ & $58.4^{\mathrm{f}}$ & & $85.8^{g}$ & $79.9^{a b}$ & $63.7^{\mathrm{ac}}$ & $59.7^{\text {bd }}$ \\
\hline TS & Post & D & $\mathrm{TS}_{\text {Post(D) }}$ & $128.3^{c}$ & & $157.0^{\mathrm{d}}$ & $67.0^{\mathrm{cd}}$ & $55.5^{\mathrm{ad}}$ & $59.8^{\text {bd }}$ \\
\hline TS & Post & $\mathrm{D} / 2$ & $\mathrm{TS}_{\text {Post(D/2) }}$ & $118.0^{c}$ & & $167.1^{\mathrm{c}}$ & $66.6^{\text {cd }}$ & $50.8^{\mathrm{cd}}$ & $42.0^{\mathrm{ef}}$ \\
\hline TS & Post & $\mathrm{D} / 4$ & $\mathrm{TS}_{\text {Post(D/4) }}$ & $157.7^{\mathrm{b}}$ & & $197.9^{b}$ & $60.8^{\mathrm{de}}$ & $48.0^{\mathrm{d}}$ & $36.6^{\mathrm{f}}$ \\
\hline $\mathrm{CS}$ & Pre & $\mathrm{D} / 3$ & $\mathrm{CS}_{\mathrm{Pre}(\mathrm{D} / 3)}$ & $37.4^{\mathrm{g}}$ & & $62.3^{\mathrm{h}}$ & $83.9^{a b}$ & $64.8^{\mathrm{ab}}$ & $66.6^{\mathrm{ac}}$ \\
\hline $\mathrm{CS}$ & Post & D & $\mathrm{CSP}_{\text {ost(D) }}$ & $37.6^{\mathrm{g}}$ & & $64.7^{\mathrm{h}}$ & $83.1^{\mathrm{ab}}$ & $62.4^{\mathrm{ac}}$ & $69.3^{\mathrm{ab}}$ \\
\hline CS & Post & $\mathrm{D} / 2$ & $\mathrm{CS}_{\text {Post(D/2) }}$ & $72.3^{\text {ef }}$ & & $121.5^{\mathrm{e}}$ & $73.4^{\mathrm{bc}}$ & $57.0^{\mathrm{ad}}$ & $49.9^{\text {ed }}$ \\
\hline CS & Post & $\mathrm{D} / 4$ & $\mathrm{CS}_{\text {Post(D/4) }}$ & $91.6^{\mathrm{d}}$ & & $154.0^{\mathrm{d}}$ & $67.2^{\mathrm{cd}}$ & $51.3^{\text {bd }}$ & $39.0^{\mathrm{f}}$ \\
\hline Control & - & - & Ctrl & $200.0^{a}$ & & $236.7^{a}$ & $54.5^{\mathrm{e}}$ & $58.3^{\text {ad }}$ & $31.7^{\mathrm{f}}$ \\
\hline Significance & & & & $* * *$ & $* * *$ & $* * *$ & ns & $* * *$ & \\
\hline \multicolumn{10}{|l|}{ Contrasts } \\
\hline 1. Herbicides us Ctrl & & & & $* * *$ & $* * *$ & $*$ & ns & $* *$ & \\
\hline 2. Post (RS vs TS) & & & & $* * *$ & $* * *$ & $* * *$ & ns & $* * *$ & \\
\hline 3. Post (RS vs CS) & & & & $* *$ & ns & ns & ns & ns & \\
\hline 4. Post (CS us TS) & & & & $* * *$ & $* * *$ & $* * *$ & $*$ & $* * *$ & \\
\hline 5. $\mathrm{D}$ os $\mathrm{D} / 2$ & & & & $* * *$ & $* * *$ & $*$ & ns & $* * *$ & \\
\hline 6. D vs D/4 & & & & $* * *$ & $* * *$ & $* * *$ & ns & $* * *$ & \\
\hline 7. D/2 us D/4 & & & & $* * *$ & $* * *$ & $*$ & ns & ns & \\
\hline 8. Pre us Post & & & & $* * *$ & $* * *$ & $* * *$ & $*$ & $* * *$ & \\
\hline
\end{tabular}

a.i., active ingredient; DAT, days after the transplant; RS, rimsulfuron, applied at the dose of $75.0 \mathrm{~g} \mathrm{ha}{ }^{-1}$ of a.i. ( $25.0 \mathrm{~g} \mathrm{ga}^{-1}$ of a.i. for each application); Pre, single herbicide application to the soil before transplanting followed by mechanical incorporation into the soil; Post, post-transplant herbigation through drip irrigation split in three applications at 30,50 and 70 days after transplant, each applying $1 / 3$ of the scheduled dose; TS, triasulfuron, applied at the dose of $22.5 \mathrm{~g} \mathrm{ha}^{-1}$ of a.i. $\left(7.5 \mathrm{~g} \mathrm{ha}^{-1}\right.$ of a.i. for each application); $\mathrm{CS}$, chlorsulfuron, applied at the dose of $15.0 \mathrm{~g}$ ha ${ }^{-1}$ of a.i. $\left(5.0 \mathrm{~g}\right.$ ha ${ }^{-1}$ of a.i. for each application). $* \mathrm{P} \leq 0.05 ; * * \mathrm{P} \leq 0.01 ; * * * \mathrm{P} \leq 0.001$; $\mathrm{ns}$, not significant. ${ }^{\mathrm{aj}} \mathrm{M}$ Means in columns not sharing the same letters are significantly different according to least significant difference test (P=0.05). ${ }^{\circ}$ In brackets and subscript the applied dose of herbicide indicated with D for the full dose, which was $75.0,22.5$ and $15.0 \mathrm{~g} \mathrm{ha}^{-1}$ of a.i. for RS, TS and CS, respectively, or D/2, D/3 and D/4, where the relative full dose of each herbicide was $1 / 2,1 / 3$ or $1 / 4$ of D, respectively. 
$\mathrm{RS}_{\operatorname{Pre}(\mathrm{D} / 3)}$ and $\mathrm{CS}_{\operatorname{Pre}(\mathrm{D} / 3)}($ Table 2)

In agreement with our outcomes, Heizenberg et al. (2004) found that pre-transplant application of different herbicides, rimsulfuron well controlled Egyptian broomrape. In our study, these results can be associated to two aspects i) the uniformity of soil incorporation of the herbicides in pre-transplant, which is strategic in reducing parasite crop infestation, and ii) early broomrape germination and attachment in the 2015 crop cycle, which occurred when herbicides, even the most degradable rimsulfuron (Sarmah and Sabadie, 2002), were still active.

Even in 2015, crop productivity was enhanced by chemical control of broomrape (Table 2, contrast no. 1, significant at $\mathrm{P} \leq 0.001$ ), however the extend of yield increase was always consistent with the effectiveness of each herbicide. In this trial indeed no crop injuries due to herbicides were detected with the naked eye, so the effect on crop productivity could be attributable to the $P$. ramosa attack intensity. As an average compared with the untreated control (54.5 $\mathrm{Mg} \mathrm{ha}^{-1}$ ), RS and CS post-transplant application resulted in higher tomato production by $47 \%$ and $37 \%$ respectively, whereas TS application only increased production by $19 \%$ (Table 2, contrasts no. 2, and 4, significant at $\mathrm{P} \leq 0.001$, contrast no. 3 , not significant), while no difference between herbicides were detected when they were given in pre-transplant. By considering the interactions between the herbicide application time and dose, RS and CS given in pre-transplant application (25.0 and $5.0 \mathrm{~g} \mathrm{ha}^{-1}$ a.i., respectively) and in herbigation at the highest dose (75 and 15 $\mathrm{g} \mathrm{ha}^{-1}$ a.i., respectively) gave the best tomato yield performance (on average 89.9 and $83.9 \mathrm{Mg} \mathrm{ha}^{-1}$, respectively), while for TS, only the pre-transplant application $\left(7.5 \mathrm{~g} \mathrm{ha}^{-1}\right.$ a.i.) was the most effective in terms of yield improvement reaching values reported for the best RS and CS treatments $\left(79.9 \mathrm{Mg} \mathrm{ha}^{-1}\right)$. The herbigation performed with the lower herbicide doses which scarcely controlled the broomrape infestation, resulted in lower crop productivity. The changes in yield between the treatments were linked to the changes both in the number of fruit per plant and in fruit weight mirroring yield behaviour. It seems however that the mean fruit weight rather than the number of fruit was affected by broomrape infestation. For all herbicides the most considerable decrease passing from the most effective to less effective treatment was indeed observed for mean fruit weight. Specifically, averaged mean fruit weight in RS, TS and CS given in pre and in post-transplant at the highest dose passed from 73, 60 and $68 \mathrm{~g}$, respectively to 57,39 and $44 \mathrm{~g}$ registered, on average, in $\mathrm{D} / 2$ and $\mathrm{D} / 3$ doses.

\section{Relationship between broomrape infestation and toma- to yield}

The relationship between $P$. ramosa infestation and crop yield observed in both years in treated and control plots is reported in Figure 5.

In the 2014 trial the foliar treatments in TS was omitted, due to the evident crop injuries that could have interfered with the relationship between broomrape presence and yield. It emerged that with the increase in parasite infestation the yield decreased following a linear trend $(y=-0.1889 x+98.01)$. In the first experiment, at the same spear intensity level, the impact of broomrape on yield seems slightly lower than the second one probably because broomrape infection occurred after the most sensitive crop phase of flowering and fruit setting, allowing the plant to develop normally.

\section{Conclusions}

This is the first research carried out on chemical control of $P$. ramosa in processing tomato in Southern Italy using sulfonylureas. Among the tested sulfonylureas, RS was the best performing a.i. in controlling branched broomrape and in the crop selectivity, followed by CS.

The distribution through drip irrigation improved herbicide efficiency so this could represent the easiest method to suggest to farmers, considering that drip irrigation is the most common irrigation system for this crop in Southern Italy. Furthermore, since 2015 RS has been registered in Italy for drip distribution at a dose of 15-27.5 $\mathrm{g} \mathrm{ha}^{-1}$ a.i. split into two or three rates. However it must be underlined that the effectiveness of drip herbigation is strictly linked to the uniform application in the field with appropriate equipments. Low herbicide dosages, must be, indeed, very slowly injected into the irrigation water to obtain an uniform distribution over all the field.

Optimal doses for drip herbigation with RS and CS were respectively 75 , and $15 \mathrm{~g} \mathrm{ha}^{-1}$ a.i., split into three rates. Nevertheless, for CS a strong limitation is represented by its high soil persistence in particular in soils with sub-alkaline $\mathrm{pH}$ and when given by drip herbigation to which is associated high risk of underground water pollution because of the potential leaching.

Soil temperatures close to the optimal values for parasite dynamic in the initial phases of the crop cycle due to the annual changes in the climatic conditions and/or to the changes in transplanting period, can promote an early appearance of broomrape. Under such conditions the pre-transplant application into the soil of herbicide seems to be useful to reduce the effective dose of RS to $25 \mathrm{~g} \mathrm{ha}^{-1}$ a.i. and of CS to $5.0 \mathrm{~g} \mathrm{ha}^{-1}$ a.i.. Triasulfuron had effec-

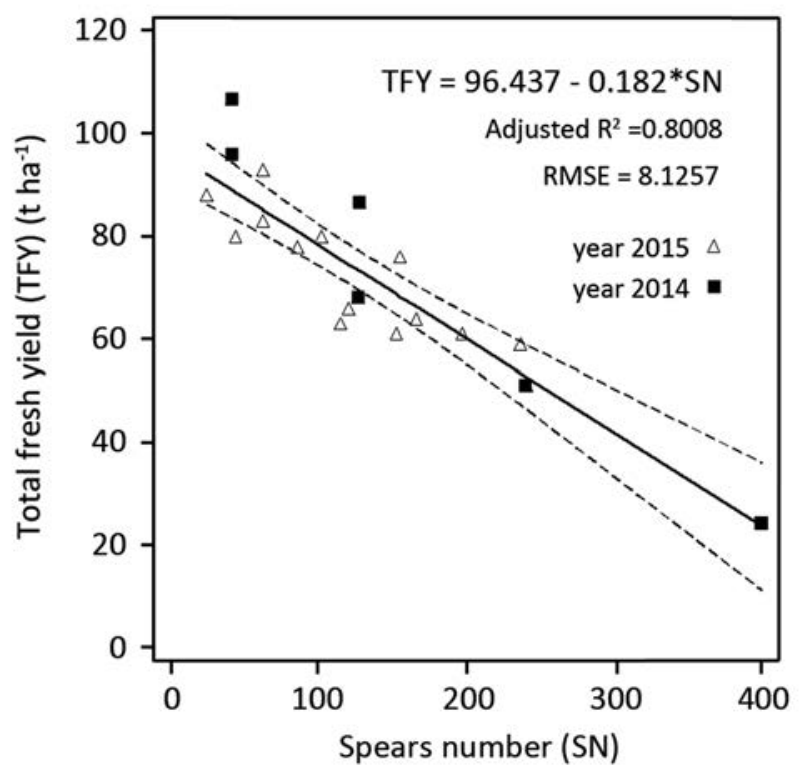

Figure 5. Relationships between tomato fruit yield and the number of branched broomrape spears in the 2014 and 2015 trials. The observed values in 2014 and 2015 are indicated with squares and triangles, respectively. The straight line represents the linear regression between the two variables, with dashed lines indicating the $95 \%$ confidence interval. Adjusted $R^{2}$ is the coefficient of determination and root mean square error represents the variance of the residuals. 
tiveness similar to RS and CS in controlling P. ramosa, and it was selective for tomato crop when given to the soil before transplanting. Based on these results, pre-transplant application of TS seems to be an achievable way since the application of this hebicide through drip herbigation has some technical difficulties due to its low mobility in the soil, which limits its distribution over the root zone and hence the efficiency. However, the results on triasulfuron are of limited interest within the EU area due to its ban occurred with the supervening EU Regulation no. 2016/864 of 31 May 2016. More research is needed to optimize herbicide control of $P$. ramosa in processing tomato under the conditions of Southern Italy in order to improve crop protection over the whole crop cycle as a function of the annual climatic variability and/or of the shift in the period of cultivation. In particular, the possibility of combining pre and post-transplant applications should be better addressed. In every case the scheduling of the split applications must respect the safety interval of each herbicide. Therefore, considering that broomrape germination starts early in the crop cycle further investigations should assess the possibility to anticipate the beginning of the applications and/or reduce their number.

\section{References}

Conversa G, Bonasia A, Di Gioia F, Elia A, 2015. A decision support system $(\mathrm{Ges} \mathrm{CoN})$ for managing fertigation in vegetable crops. Part II - model calibration and validation under different environmental growing conditions on field grown tomato. Front. Plant Sci. 6:495.

Dhanapal GN, Struik PC, Udaya Kumar M, Timmermans PCJM, 1996. Management of broomrape (Orobanche spp.). A review. J. Agron. Crop Sci. 175:335-59.

Dinesh MS, Dhanapal GN, 2013. Chemical control of Orobanche cernua in tomato fields in Karnataka. Bioinfolet. 10:187-90.

Eizenberg H, Aly R, Cohen Y, 2012. Technologies for smart chemical control of broomrape (Orobanche spp. and Phelipanche spp.). Weed Sci. 60:316-23.

Eizenberg H, Goldwasser Y, Golan S, Plakhine D, Hershenhorn J, 2004. Egyptian broomrape (Orobanche aegyptiaca) control in tomato with sulfonylurea herbicides - greenhouse studies. Weed Technol. 18:490-6.

Eizenberg H, Hershenhorn J, Ephrath JH, Kanampiu F, 2013. Chemical control. In: D.M. Joel, J. Gressel, L.J. Musselman (eds.) Parasitic Orobanchaceae: parasitic mechanisms and control strategies. Springer-Verlag, Berlin, Germany, pp 415-32.

Eizenberg H, Hershenhorn J, Graph S, Manor H, 2003. Orobanche aegyptiaca control in tomato with sulfonylurea herbicides. Acta Hortic. 613:205-8.

Elia A, Conversa G, 2012. Agronomic and physiological responses of a tomato crop to nitrogen input. Eur. J. Agron. 40:64-74.

Elia A, Conversa G, 2015. A decision support system (GesCoN) for managing fertigation in open field vegetable crops. Part Imethodological approach and description of the software. Front. Plant Sci. 6:319.

Ghannam I, Al-Masri M, Barakat R, 2012. The effect of herbicides on the Egyptian broomrape (Orobanche aegyptiaca) in tomato fields. Am. J. Plant Sci. 3:346-52.

Gibot-Leclerc S, Corbineau F, Salle G, Côme D, 2004. Responsiveness of Orobanche ramosa L. seeds to GR24 as related to temperature, oxygen availability and water potential during preconditioning and subsequent germination. Plant Growth Reg. 43:63-71.

Goldwasser Y, Eizenberg H, Hershenhorn J, Plakhine D, Blumenfeld T, Buxbaum H, Golan S, Kleifeld Y, 2001. Control of Orobanche aegyptiaca and O. ramosa in potato. Crop Protect. 20:403-10.

Hershenhorn J, Eizenberg H, Dor E, Kapulnik Y, Goldwasser Y, 2009. Phelipanche aegyptiaca management in tomato. Weed Res. 49(Suppl.1):34-7.

Hershenhorn J, Goldwasser Y, Plakhine D, Ali R, Blumenfeld T, Bucsbaum H, Herzlinger G, Golan S, Chilf T, Eizenberg H, Dor E, Kleifeld Y, 1998a. Orobanche aegyptiaca control in tomato fields with sulfonylurea herbicides. Weed Res. 38:343-9.

Hershenhorn J, Goldwasser Y, Plakhine D, Lavan Y, Herzlinger G, Golan S, Chilf T, Kleifeld Y, 1998b. Effect of sulfonylurea herbicides on Egyptian broomrape (Orobanche aegyptiaca) in tomato (Lycopersicon esculentum) under greenhouse conditions. Weed Technol. 12:115-20.

Hershenhorn J, Plakhine D, Goldwasser Y, Westwood JH, Foy CL, Kleifeld Y, 1998c. Effect of sulfonylurea herbicides on early development of Egyptian broomrape (Orobanche aegyptiaca) in tomato (Lycopersicon esculentum). Weed Technol. 12:108-14.

ISTAT, 2017. Electronic information system on agriculture and livestock. Italian National Statistical Institute (ISTAT), Rome. Available from: http://agri.istat.it/

Joel DM, Steffens JC, Matthews DE, 1995. Germination of weedy root parasites. In: J. Kigel, G. Galili (eds.) Seed development and germination. Marcel Dekker Inc., New York, USA, pp 567-97.

Kebreab E, Murdoch AJ, 1999. Modelling the effects of water stress and temperature on germination rate of Orobanche aegyptiaca seeds. J. Exp. Bot. 50:655-64.

Kleifeld Y, Goldwasser Y, Herzlinger G, Golan S, Blumenfeld T, Buxbaum H, 1994. Selective control of broomrape in tomatoes with rimsulfuron. In: A.H. Pieterse, J.A.C.Verkleij, S.J. ter Borg (eds.) Biology and management of Orobanche. Proceedings of the third international workshop on orobanche and related striga research, Royal Tropical Institute, Amsterdam, the Netherlands, pp 561-71.

Longo AMG, Lo Monaco A, Mauromicale G, 2010. The effect of Phelipanche ramosa infection on the quality of tomato fruit. Weed Res. 50:58-66.

Murdoch AJ, Kebreab E, 2013. Germination ecophysiology In: D.M. Joel, J. Gressel, L.J. Musselman (eds.), Parasitic Orobanchaceae: parasitic mechanisms and control strategies, Springer-Verlag, Berlin, Germany, pp 195-219.

Qasem JR, 1998. Chemical control of branched broomrape (Orobanche ramosa) in glasshouse grown tomato. Crop Protect. 17:625-30.

Sarmah AK, Sabadie J, 2002. Hydrolysis of sulfonylurea herbicides in soils and aqueous solutions: a review. J. Agric. Food Chem. 50:6253-65.

SAS Institute, 1999. SAS Version 8.02. SAS Institute Inc, Cary, NC, USA.

Vurro M, Domina G, 2005. Development of the broomrape problem in Italy. Proceedings of the Workshop Means for limiting Orobanche propagation and dispersal in agricultural fields. Abstr. 5, NeweYaar, Israel, 4-6 December 2005. Available from: http://cost849.ba.cnr.it/Proceedings\%20COST\% 20Workshop, \%20Israel.pdf

Walker A, Welch SJ, 1989. The relative movement and persistence in soil of chlorsulfuron, metsulfuron methyl and triasulfuron. Weed Res. 29:375-83. 